Dept. of Animal Hygiene and Zoonoses,

Fac. Vet. Medicine, Assiut Univ.

\title{
SURVEILLANCE OF METHICILLIN RESISTANT STAPHYLOCOCCUS AUREUS (MRSA) IN RAW MILK AND MILK HANDLERS WITH NUC GENE SEQUENCING OF THE ISOLATED STRAINS
}

(With 2 Tables and 2 Figures)

\author{
By \\ AMAL S.M. SAYED and ASMAA A. HUSSEIN \\ (Received at 4/9/2010)
}

مدى تواجد methicillin resistant S. aureus فى اللبن الخام والقائمين على حلب الحيوانات ودراسة تتابع nuc gene للعترات المعزولة

أمل سبي محد سبا ، أسعاء عبل الناصر حسين

في الآونة الأخيرة تزايدت خطورة ميكروبات methicillin resistant S. aureus على صحة الإن الإن الإن

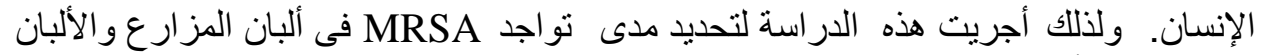

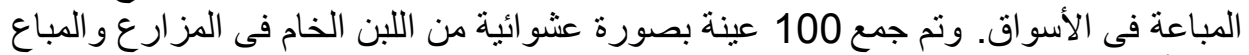

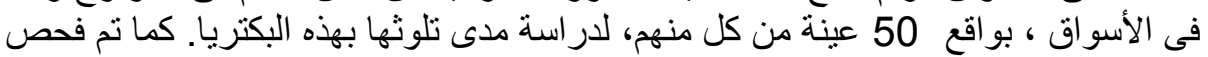

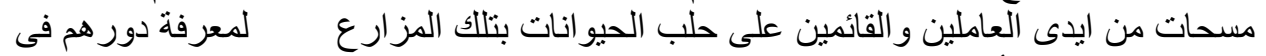

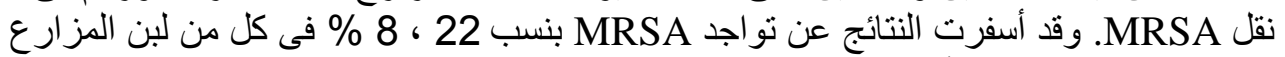

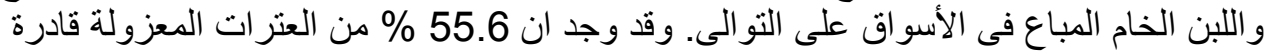

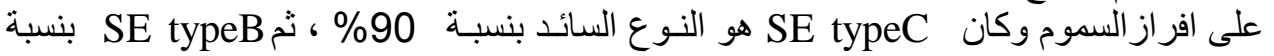

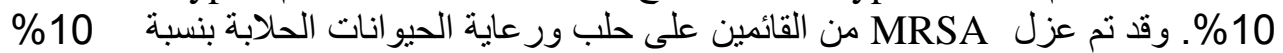

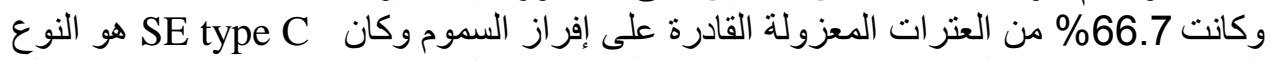

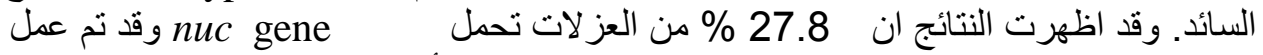

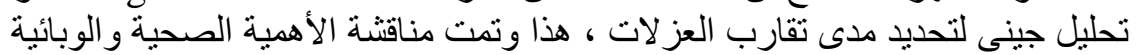

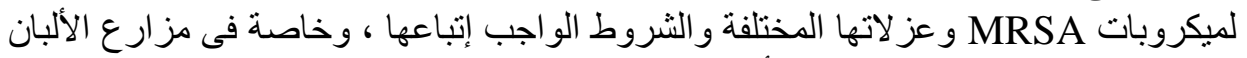
من تو عبة للعاملين بها لمنع تلوث الألبان بهذه الميكروبات لدر الته خطر ها عن المستهلاك.

\section{SUMMARY}

The emergence and spread of methicillin resistant Staphylococcus aureus (MRSA) infections are considered a global health issue. This study was designed to determine the prevalence of MRSA in milk from dairy herds and markets. The role of milk handlers as a source of MRSA infection had been studied. Genotyping of the isolated MRSA strains was investigated. A total of 100 samples of farm milk and market milk (50 each) as well as 30 
hand swabs of milk handlers were collected randomly from Assiut Governorate. Methicillin resistant Staphylococcus aureus was isolated and enterotoxigenic strains were investigated. Polymerase chain reaction (PCR) was performed to amplify the nuc gene in the isolated strains. Moreover, sequencing of the amplified PCR products and phylogenetic analysis was performed. MRSA strains were isolated from $13.85 \%$ of the examined samples $(22 \%$ and $8 \%$ of the examined farm and market milk, respectively) and $55.6 \%$ of the isolated MRSA strains were enterotoxigenic. In this study, staphylococcal enterotoxin $\mathrm{C}$ was the most enterotoxin detected in the isolated MRSA strains with a rate of $90 \%$. However, enterotoxin type B was detected in $10 \%$ of the isolated MRSA strains. In addition, $25 \%$ of MRSA strains isolated from market milk were enterotoxigenic with one strain belong to type C. Enterotoxigenic MRSA strains were isolated with a rate of $66.7 \%$ from milk handlers and enterotoxin type C was the type of toxin produced by these strains. Nuc gene was detected in $5(27.8 \%)$ out of the 18 MRSA strains. Phylogenetic analysis of the amplified products sequences was done and the results were discussed. Public health hazard of MRSA was discussed and suggestive measures for control were explained.

Key words: MRSA, milk, milk handler, PCR, Nuc gene, sequencing.

\section{INTRODUCTION}

The emergence and spread of methicillin resistant Staphylococcus aureus (MRSA) infections are considered a global health issue (Normanno et al., 2007). MRSA organisms are frequently resistant to most of the commonly used antimicrobial agents, including the aminoglycosides, macrolids, chloramphinicol, tetracycline and fluoroquinolones (Mandell et al., 1995). Although $S$. aureus is a serious problem in dairy production causing subclinical and clinical mastitis in dairy herds, there is a limited number of publications on the epidemiological aspects of MRSA infections in dairy herds (Devriese and Hommez, 1975; Seguin et al., 1999; Lee, 2003 and Normanno et al., 2007).

New evidence also suggests that domestic animals including food animals are capable of serving as reservoirs and shedders of MRSA and that transmission between host species may be possible (Loo et al., 2007 and Normanno et al., 2007). Human handlers, infected animals, milking equipments and the environment are implicated as possible sources of bulk milk contamination in dairy herds (Zadoks et al., 2002). Recent studies have shown genetic similarity between MRSA isolates from food animals, 
including dairy cows and those in humans, suggesting a mode of transmission between them (Juhasz-Kazanyitz et al., 2007 and Moon et al., 2007).

Food borne acquired MRSA outbreaks have been reported and most of them occurred from milk and milk products (Kluytmans et al., 1995; De Buyser et al., 2001; Jones et al., 2002 and Lee, 2003). Food associated intoxication are commonly mediated by heat-stable staphylococcal enterotoxins (Wilson et al., 1991). To date, 18 staphylococcal enterotoxins (SEs) have been described and designed SEA to SEE; SEG to SER and SEU (Dings et al., 2000; Jarraud et al., 2001; Leterte et al., 2003).

This study was designed to determine the prevalence of MRSA in milk from dairy farms and markets. The role of milk handlers as a source of MRSA infection had been studied and genotyping of the isolated MRSA strains was investigated.

\section{MATERIALS and METHODS}

\section{Sample collection}

A total of 100 samples of farm milk and market milk (50 each) were collected randomly from Assiut Governorate in the period from March to August 2008. Moreover, 30 swabs of hands of milk handlers were obtained. Each swab was emulsified in sterile physiological saline.

\section{Isolation of methicillin resistant $S$. aureus (MRSA):}

$1 \mathrm{ml}$ of each milk sample or $1 \mathrm{ml}$ of swab emulsion were enriched in tryptone soya broth (TSB) containing $70 \mathrm{mg} / \mathrm{ml} \mathrm{NaCl}$ and incubated at $37^{\circ} \mathrm{C}$ for $18-20 \mathrm{~h}$. A loopfull from the enriched media was plated onto selective medium for MRSA isolation (Mannitol salt agar containing oxacillin $4 \mathrm{mg} / \mathrm{litre}$ ) and incubated at $37^{\circ} \mathrm{C}$ for $24-48 \mathrm{~h}$. MRSA strains are capable of fermenting mannitol within $24 \mathrm{~h}$. (Indicated by a color change from red to yellow) however, few strains of MRSA ferment mannitol slowly, so negative plates after $24 \mathrm{~h}$ should be incubated for additional $24 \mathrm{~h}$ (Compernolle et al., 2007). Presumptive colonies were identified as $S$. aureus by using conventional methods including Gram stain, catalase, DNase, Voges-Proskauer and mannitol fermentation tests.

\section{Coagulase test:}

Tube coagulase test for detection of free coagulase was performed with rabbit plasma (BioMereux). The test was performed by diluting the plasma in freshly prepared normal saline (1:6). Four pure colonies were emulsified in $1 \mathrm{ml}$ diluted plasma and incubated at $37^{\circ} \mathrm{C}$. The tubes were 
inspected at $1 \mathrm{~h}, 2 \mathrm{~h}, 3 \mathrm{~h}$ and $4 \mathrm{~h}$ and incubated overnight if no clot formation was observed (Baired, 1996).

\section{Detection of Staphylococcal enterotoxins (SEs):}

The isolated $S$. aureus strains were grown in tryptone soya broth and incubated at $37^{\circ} \mathrm{C}$ for $24 \mathrm{~h}$. The cultures were centrifuged for $5 \mathrm{~min}$. at $3500 \mathrm{rpm} / 15^{\circ} \mathrm{C}$. The supernatant was filtered through $0.45 \mu \mathrm{m}$ low-protein binding filter and the filtrate was used for enterotoxin detection. Detection of enterotoxins (A,B,C,D,E) was done by using ELISA test kit (RIDASCREEN SET A,B,C,D,E (R- Biopharm AG, Darmstadt, Germany) according to the manufacturer's procedure.

\section{PCR assay for detection of nuc gene:}

DNA of the $S$. aureus colonies was extracted by using QIAamp DNA mini kit (Qiagen, $\mathrm{GmbH}$ ) according to the manufacturer's protocol. The $n u c$ gene, which encodes thermonuclease was used as a target DNA to identify $S$. aureus .The primers

F 5'-GCGATTGATGGTGATACGGTT-3' and

R 5'AGCCAAGCCTTGACGAACTAAAGC -3' (Brakstad et al., 1992) were used to amplify $n u c$ gene. The Amplification was carried out in $0.5 \mathrm{ml}$ tubes in a final reaction volume $50 \mu$. The PCR mixture consisted of 1.5 $\mathrm{mM} \mathrm{MgCl} 2,10 \mathrm{mM}$ Tris- $\mathrm{HCl}$ (pH 9.0). 50mM KCl. $0.1 \%$ Triton®X-100, $200 \mu \mathrm{M}$ (each) deoxynucleotide triphosphate, $0.2 \mu \mathrm{M}$ of each primer and $0.625 \mathrm{U}$ Taq polymerase. The PCR was conducted in a Biometra Thermal cycler (Biometra - Germany) and the amplification condition was one cycle of $95^{\circ} \mathrm{C}$ for $10 \mathrm{~min}$, followed by 37 cycles of $94^{\circ} \mathrm{C}$ for $1 \mathrm{~min}, 50^{\circ} \mathrm{C}$ for $30 \mathrm{sec}$, and $72^{\circ} \mathrm{C}$ for $1.5 \mathrm{~min}$ and final extension at $72^{\circ} \mathrm{C}$ for $5 \mathrm{~min}$. PCR products $(10 \mu \mathrm{l})$ were analyzed by electrophoreses on $2 \%$ agarose gel containing ethidium bromide and visualized under UV illumination and PCR product size is $270 \mathrm{bp}$.

\section{Sequencing of the amplified PCR products:}

Sequences of the PCR products were determined by the dideoxy chain termination method using Big Dye Terminator v 3.1 Cycle sequencing Kit according to the manufacturer's cycle sequencing protocol.

\section{Phylogenetic analysis:}

The $n u c$ gene sequences were aligned with CLUSTAL W software (Thompson et al., 1994) and examined using the program MEGA (Molecular Evolutionary Genetics Analysis) version 4 (Tamura et al., 2007). Phylogenetic tree was constructed by the neighbor-joining method with the distance algorithms in the MEGA package. Bootstrap values were determined with 1000 replicates of the data set and compared with 
$S$. aureus strains registered in the DDBJ/EMBL/GeneBank including: S. aureus EMRSA 16 (Accession No: ADAT01000022.1); S. aureus ST 398 (Accession No: AM990992.1), S. aureus ED 133 (Accession No: CP001996.1), S. aureus JKD 6008 (Accession No: CP002120.1), S. aureus TW 20 (Accession No: FN433596.1).

\section{RESULTS}

Table 1: Prevalence of MRSA strains in the examined samples

\begin{tabular}{|l|c|c|c|c|c|}
\hline Source of samples & $\begin{array}{c}\text { No. of } \\
\text { samples }\end{array}$ & MRSA & $\%$ & $\begin{array}{c}\text { MRSA } \\
\text { (nuc gene) }\end{array}$ & $\%$ \\
\hline Farm milk & 50 & 11 & 22 & 3 & 27.3 \\
\hline Market milk & 50 & 4 & 8 & 1 & 25 \\
\hline Milk handlers & 30 & 3 & 10 & 1 & 33.3 \\
\hline Total & 130 & 18 & 13.85 & 5 & 27.8 \\
\hline
\end{tabular}

Table 2: Incidence of enterotoxigenic MRSA with enterotoxins typing

\begin{tabular}{|l|c|c|c|c|c|c|c|c|}
\hline \multirow{2}{*}{$\begin{array}{c}\text { Source of } \\
\text { samples }\end{array}$} & \multirow{2}{*}{ MRSA } & \multirow{2}{*}{$\begin{array}{c}\text { Enterotoxigenic } \\
\text { strains }\end{array}$} & \multicolumn{5}{|c|}{ Type of toxins } \\
\cline { 5 - 9 } & & \multicolumn{2}{|c|}{} & A & B & C & D & E \\
\hline Farm milk & 11 & 7 & 63.6 & - & $1(14.3 \%)$ & $6(85.7 \%)$ & - & - \\
\hline Market milk & 4 & 1 & 25 & - & - & $1(100 \%)$ & - & - \\
\hline Milk handlers & 3 & 2 & 66.7 & - & - & $2(100 \%)$ & - & - \\
\hline Total & 18 & 10 & 55.6 & - & $1(10 \%)$ & $9(90 \%)$ & - & - \\
\hline
\end{tabular}




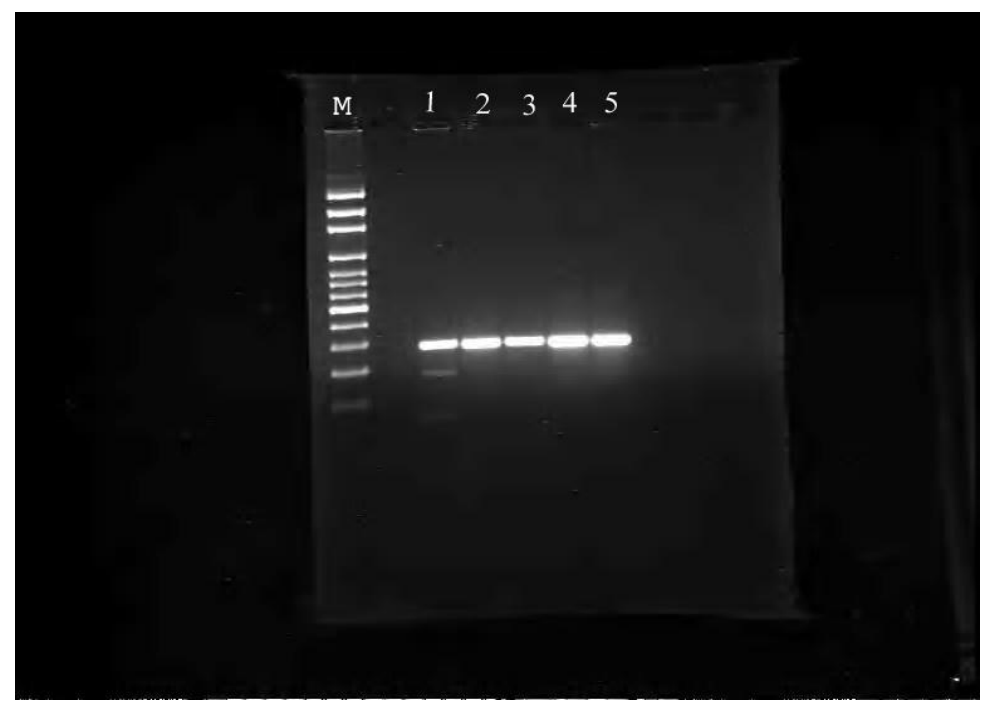

Fig. 1: PCR identification of MRSA, nuc gene

M: 100 bp DNA size marker. Lanes 1, 2, 3, 4, 5: MRSA strains positive for $n u c$ gene (270bp).

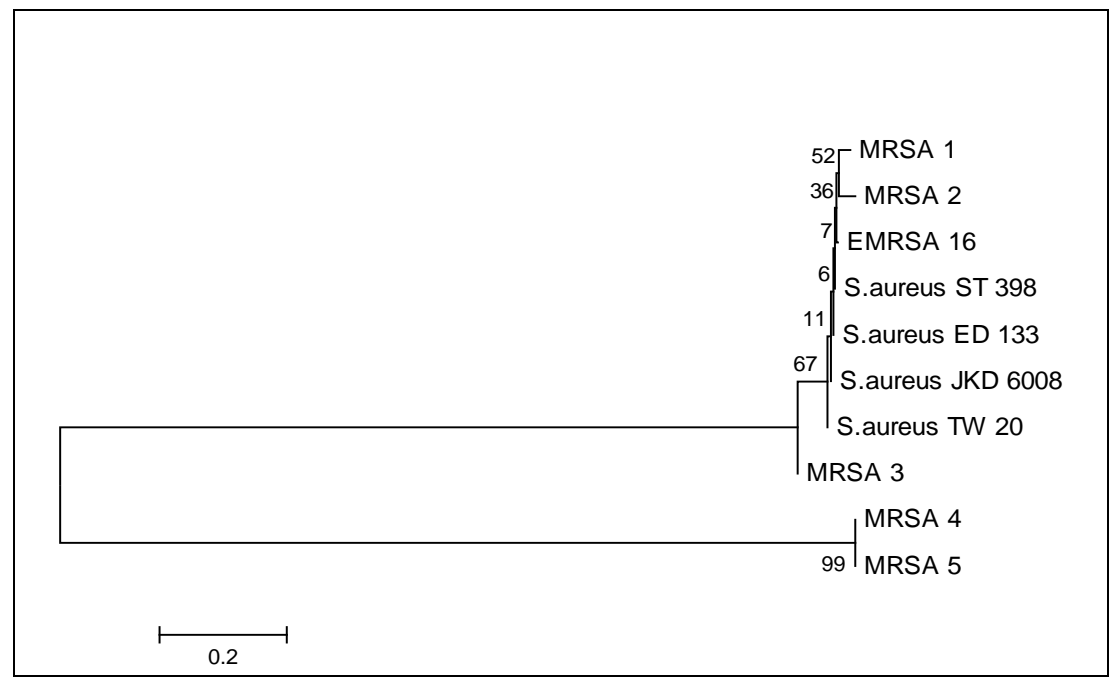

Fig. 2: Phylogenetic tree of $n u c$ gene sequences

MRSA1, MRSA 4, MRSA 5 strains obtained from farm milk

MRSA 2: strain obtained from market milk

MRSA 3 strain obtained from milk handler.

S. aureus strains (EMRSA 16, S. aureus ST 398, S. aureus ED 133,

S. aureus JKD 6008, S. aureus TW 20)

registered in the DDBJ/EMBL/Gene Bank. 


\section{DISCUSSION}

The improper use of antibiotics in dairy herds especially in mastitis control in lactating and dry cows had lead to the emergence of bacterial resistant strains into the food chain and thus considered a public health hazard (White and McDermontt, 2001 and Lee, 2003).

Coagulase positive MRSA strains were isolated from $13.85 \%$ of the examined samples (Table 1). MRSA strains were isolated from $22 \%$ and $8 \%$ of the examined farm and market milk, respectively (Table 1). It has been isolated with a lower prevalence rates $(3 \%)$ and $(2.8 \%)$ in other studies (Lee, 2006 and Moon et al., 2007), respectively. Higher prevalence rate $(42.9 \%)$ was reported in another study (Lee, 2003).

In this study $55.6 \%$ of the isolated MRSA strains (Table 2) were enterotoxigenic. A similar result was reported previously by Jorgensen et al., 2005. However, variable rates of enterotoxigenic MRSA strains were reported $42.9 \%$ and $74 \%$ by Adesiyun et al., 1998 and Valle et al., 1990, respectively. Staphyloccol enterotoxin $\mathrm{C}$ was the most enterotoxin detected in the isolated MRSA strains with a rate of $90 \%$ however, enterotoxin type $\mathrm{B}$ was detected in $10 \%$ of the isolated MRSA strains (Table 2). Our result is in concurrent with Wilson et al., 1991 who reported that Staph enterotoxin type $\mathrm{C}$ was the enterotoxin most commonly associated with dairy products. $63.6 \%$ of the isolated MRSA strains from farm milk were enterotoxigenic where, 6 (85.7\%) strains belong to type $\mathrm{C}$ and one strain belong to type B (14.3\%) (Table 2). However, 25\% of MRSA strains isolated from market milk were enterotoxigenic with one strain belong to type C (Table 2). Normanno et al., 2007 reported that the most frequently detected (SE) was SED alone or in association with either SEA and SEC.

Enterotoxigenic MRSA strains were isolated from $10 \%$ of the examined milk handlers (Table 1) and $66.7 \%$ from the strains produced enterotoxin type C (Table 2). However, S. aureus strains were isolated from hand swabs of milkers belonged to SEC, SEB and SEA with a rate of $32.4 \%, 24.3 \%$ and $13.5 \%$, respectively (Adesiyun et al., 1998).

Corrente et al. (2005) found that SEA was the prevalent SE synthesized by MRSA strains isolated from humans. The presence of enterotoxigenic strains in milk handlers emphasizes the role of human as an important reservoir for MRSA and their potential role of contamination of milk during handling.

Multiple studies have characterized the genotypic diversity of S. aureus from cases of bovine mastitis (Sabour et al., 2004) but few have investigated S. aureus from bulk milk (Casciano et al., 2003 and Scherrer et al., 2004). Knowledge about the genotypic variation among S. aureus 
isolates from bulk milk could aid in the implementation of strategies to decrease $S$. aureus level in bulk milk and could be useful in future investigation of staph food poisoning (SFP) from raw milk products in the presence of certain genotypes in the product might point to a possible source of contamination (Jorgensen et al., 2005). Moreover, DNA sequencing is a useful tool in epidemiological investigation to observe the genotypic variation and to determine the relation between the isolates.

Although the isolated MRSA strains was identified by conventional methods, only 5 (27.8\%) out of the 18 MRSA strains were positive for $n u c$ gene by PCR (Table $1 \&$ Figure 1). This discrepancy could be explained by polymorphism of primer annealing site or partial deletion of the nис gene in the MRSA negative strains (Klaassen et al., 2003). Similar results were reported by Loo et al. (2007) and Kateete et al. (2010). The possibility of mutation needs to be considered in the design of probes and primers to avoid false negative or inaccurate quantitative PCR. The use of single species specific gene as target for molecular based MRSA screening may lead to misidentification. It is better to incorporate an additional internal species specific gene detection to increase strain coverage and identification (Van Leeuwen et al., 2008).

The phylogenetic analysis (Figure 2) classified the MRSA 4 and MRSA 5 into a separate clade from MRSA 1, MRSA 2 and MRSA 3. MRSA 4 and MRSA 5 are closely related to each other however, both of them had relatively low level of homology with sequences from MRSA 1, MRSA 2 and MRSA 3. Interestingly, MRSA 4 and MRSA 5 were isolated from the same farm and phylogenetic analysis revealed that they are epidemiologically related. On the other hand, MRSA 1 and MRSA2 are epidemiologically related, although MRSA 1 was isolated from farm milk and MRSA 2 were isolated from market milk and this result points out to the same source of MRSA from the farm. The genetic variation of nuc gene sequence between MRSA 1, MRSA 2 and MRSA 4 \& MARSA 5 may be attributed to geographic variation. MRSA 3 was isolated from milk handler and had relatively low level of homology with MRSA 1, MRSA 2, MRSA 4 and MRSA 5. This result reveals the genetic variation between the strains isolated from milk and that isolated from human. The sequence of MRSA strains obtained in this study was compared with 5 strains registered in the DDBJ/EMBL/Gene Bank and phylogenetic analysis revealed that MRSA 1 and MRSA 2 are closely related to $S$. aureus strains (EMRSA 16, S. aureus ST 398, S. aureus ED 133, S. aureus JKD 6008, S. aureus TW 20) registered in the DDBJ/EMBL/Gene Bank. However, MRSA 3, MRSA 4 and MRSA 5 had relatively low homology with them (Figure 2). 
Presence of MRSA strains in milk may constitute a lethal risk for consumers, especially for immunocompromised individuals where their immune system are not able to act as barriers to prevent colonization of the gastrointestinal tract (Kluytmans et al., 1995). It is recommended that infected cows with $S$. aureus should be rapidly culled or treated early with antimicrobial dry cow therapy to prevent the transmission to healthy cows and to control the somatic cell count in bulk tank milk. Efficient chilling of bulk milk until pasteurization, followed by efforts to prevent recontamination minimizes the risk of SFP. Better sanitary education of milk handlers on sanitary practices focusing on their potential role as reservoirs and spreaders of food borne pathogens is recommended.

\section{REFERENCES}

Adesiyun, A.A.; Webb, L.A. and Romain, H.T. (1998): Prevalence and characteristics of Staphylococcus aureus strains isolated from bulk and composite milk and cattle handlers. J. Food Protec. 61(5): 629-632.

Baired, D. (1996): Staphylococcus: cluster forming gram positive cocci. In Mackie \& Mac Cartney Practical Medical Microbiology. 14 th edition. Edited by: Collee J.G., Fraser, A.G.; Marmion, B.P; Simmons, A. New York; Churchill Livingstone. pp 245-261.

Brakstad, O.G.; Asbakk, K. and Macland, J.A. (1992): Detection of Stapylococcus aureus by polymerase chain reaction amplification of $n u c$ gene. J. Clinic. Microbiol. 30: 1654-1660.

Casciano, R.; Alberghini, L.; Peccio, A; Serraino, A. and Rosmni, R. (2003): Typing of Stapylococcus aureus isolates from raw milk. Vet. Res. Commun. 27 (1): 289-291.

Compernolle, V.; Verschraegen, G. and Claeys, G. (2007): Combined use of Pastorex Staph- plus and either of two new chromogenic agars, MRSA ID and CHROM agar MRSA, for detection of methicillinresistant Stapylococcus aureus. J. Clinic. Microbiol. 45(1): 154- 158.

Corrente, M.; Monno, R; Totano, M.; Marella, V.; Buonavoglia, D.; Rizzo, C.; Ricci, D.; Rizzo, G. and Buonavoglia, C. (2005): Characterization of methicillin- resistant Stapylococcus aureus (MRSA) isolated at the Policlinico Hospital of Bari (Italy). The New Microbiolgica 28: 57-65. 
De Buyser, M.L.; Dufour, B.; Maire, M. and Lafarge, V. (2001): Implication of milk and milk products in food borne diseases in France and in different industrialized countries. Int. J. Food Microbiol. 67: 1-17

Dinges, M.M.; Orwin, P.M. and Schlievert, P.M. (2000): Exotoxins of Staphylococcus aureus. Clinic. Microbiol. Rev. 13:16-34.

Diverse, L.A. and Hommez, J. (1975): Epidemiology of methicillin resistant Staphylococcus aureus in dairy herds. Res. Vet. Sci. 19: 23-27.

Jarraud, S.; Peyrat, A.M.; Lim, A.; Tristan, A.; Bes, M.; Maugel, C.; Etienne, J.; Vandenesch, F.; Bonneville, M. and Lina, G. (2001): ecg, a highly prevalent operon of enterotoxin gene, forms a putative nursery of superantigen in Staphylococcus aureus. J. Immunol.166: 669-677.

Jones, T.F.; Kellum, M.E.; Porter, S.S.; Bell, M. and Schaffiner, W. (2002): An outbreak of community-acquired food borne illness caused by methicillin resistant Staphylococcus aureus. Emerging Infect. Dis. 8: 82-84.

Jorgensen, J.H.; Mork, T.; Caught, A.D.; Kearn, A. and Rorvilk, M.L. (2005): Genetic variation among Staphylococcus aureus strains from Norwegian bulk milk. Appl. Environ. Microbiol. 71(12): 8352-8361.

Juhasz- Kaszanyitzky, E.; Janosi, S.; Somogyi, P.; Dan, A; VanderGraafVan Bloois, L.; Van Duijkeron, E. and Wagenaar, J.A. (2007): MRSA transmission between cows and humans. Emerg. Infect. Dis. 13: 630-632.

Kateete, D.P.; Kimani, C.N.; Katabazi, F.A.; Okeng, A.; Okee, M.S.; Nanteza, A.; Joloba, M.L. and Najjuka, F.C. (2010): Identification of Staphylococcus aureus: DNase and Mannitol salt agar improve the efficiency of the tube coagulase test. Annals of Clinical Microbiology and Antimicrobials. 9: 23-29.

Klassen, C.H.; de Valk, H.A. and Horrevorts, A.M. (2003): Clinical Staphylococcus aureus isolate negative for the Sa 442 fragment. J. Clinic. Microbiol. 41: 4493

Kluytman, J.; Van leeuwen, W.; Goessens, W.; Hollis, R.; Messer, S.; Herwarld, L.; Bruining, H.; Heck, M.; Rost, J.; Van Leeuven, N.; Van Belkum, A. and Verburg, H. (1995): Food initiated outbreak of methicillin resistant Staphylococcus aureus analyzed by phenol- and genotyping. J. Clinic. Microbiol. 33: 1121-1128. 
Lee, J.H. (2006): Occurrence of methicillin -resistant Staphylococcus aureus strains from cattle and chicken, and analyses of their mecA, mecRI and mecI genes. Vet. Microbiol. 114: 155-159.

Lee, J.H. (2003): Methicillin (oxacillin) resistant Staphylococcus aureus strains isolated from major food animals and their potential transmission to humans. Appl. Environ. Microbiol. 69: 6489-6494.

Leterte, C.; Perelle, S.; Dilasser, F. and Fech, P. (2003): Identification of a new putative enterotoxin SEU encoded by the egc cluster of Staphylococcus aureus. J. Appl. Microbiol. 95: 38-43.

Loo, I.; Huijsdens, X.; Tiermersma, F.; Neeling, A.; Van de sandeBrnisma, D.; Beanjean, D.; Voss, A. and Klutmans, J. (2007): Emergence of methicillin- resistant Stapylococcus aureus animal orign in humans. Emerg. Infect. Dis. 13: 1834-1839.

Mandell, G.; Douglas, J. and Benett, R. (1995): Principles and practices of infectious diseases, $4^{\text {th }}$ ed. Churchill Livingstone, Ltd, Edinburg, United Kingdom.

Moon, J.S.; Lee, A.R.; Kang, H.M.; Lee, E.S.; Kim, M.N.; Paik, Y.H.; Park, Y.H.; Joo, Y.S. and Koo, H.C. (2007): Phenotypic and genetic antibiogram of methicillin-resistant Staphylococci isolated from bovine mastitis in Korea. J. Dairy Sci. 90: 1176-1185.

Normanno, G.; Corrente, M.; Salandra, La, G.; Dambrosio, A.; Quaglia, N.C.; Parisi, A.; Gerco, G.; Bellacicco, L.A.; Virgillo, S. and Celano, V.G. (2007): Methicillin-resistant Staphylococcus aureus (MRSA) in foods of animal origin product in Italy. Int. J. Food Microbiol. 117: 219-222.

Sabour, P.M.; Gill, J.J.; Lepp, D.; Pecan, J.C.; Ahmed, R.; Dingwell, R. and Lesile, K. (2004): Molecular typing and distribution of Stapylococcus aureus isolates in Eastern Canadian dairy herds. J. Clinic. Microbiol. 42: 3449-3455.

Scherrer, D.; Corti, S.; Muehlherr, E.; Zweifel, C. and Stephan, R. (2004): Phenotyping and genotypic characterstics of Staphylococcus aureus from raw bulk tank milk samples of goats and sheep. Vet. Microbiol. 101: 101-107.

Seguin, J.C.; Walker, R.D.; Caron, J.P.; Kloos, W.E.; George, C.G.; Hollis, R.J.; Johnes, R.N. and Pfaller, M.A. (1999): Methicillinresistant Staphylococcus aureus outbreak in a veterinary teaching hospital; potential human to animal transmission. J. Clinic. Microbiol. 37: 1459-1463. 
Tamura, K.; Dudley, J.; Nei, M. and Kumar, S. (2007): Molecular Evolutionary Genetics Analysis (MEGA) software version 4.0. Mol. Biol. Evol. 24: 1596-1599.

Thompson, J.D.; Higgins, D.G. and Jibson, T.J. (1994): CLUSTAL W: improving the sensitivity of progressive multiple sequence weighting, position-specific gap penalties and weight matrix choice. Nucleic Acids Res. 22: 4673-4680.

Valle, J.; Gomez-Lucia, E.; Priz, S.; Goyuche, J.; Orden, J.A. and Vadillo, S. (1990): Enterotoxin production by Staphylococcus aureus isolated from healthy goats. Appl. Environ. Microbiol. 56: 1323-1326.

Van Leeuwen, W.; Roorda, L.; Hendrik, W.; Francois, P. and Schrenzel, J. (2008): A nuc deficient methicillin- resistant Staphylococcus aureus strain. FEMS Immunol. Med. Microbiol.54: 157.

White, D.G. and McDermott, P.F. (2001): Emergence and transfer of antibacterial resistance. J. Dairy Sci. 84(E Suppl.): 151-155.

Wilson, I.G.; Cooper, J.E. and Gilmour, A. (1991): Detection of enterotoxigenic Staphylococcus aureus in dried skimmed Milk: Use of the polymerase chain reaction for amplification and detection of Staphylococcal enterotoxin genes ent $B$ and ent $C$, and the thermonuclease Gene nuc. Appl. Environ. Microbiol. 57(6): 1793-1798.

Zadoks, R.V.; Van Leeuwen, W.B.; Kreft, D.; Fox, L.K.; Barkema, H.W. Schukken, Y.H. and Van Belkum, A. (2002): Comparison of Staphylococcus aureus isolates from bovine and human skin, milking equipment and bovine milk by phage typing pulsed field gel electrophoreses and binary typing. J. Clinic. Microbiol. 40: 3894-3902. 